UDK: $330.34: 28$

Pregledni članak

Primljeno: 9. 7. 2021.

Prihvaćeno za štampu: 22. 11. 2021.

\author{
Mr. sc. Vedad Mustedanagić, as. \\ Univerzitet u Bihaću \\ Islamski pedagoški fakultet \\ E-mail: vedadm1997@gmail.com
}

\title{
ODRŽIVI RAZVOJ IZ ISLAMSKE PERSPEKTIVE
}

\section{Sažetak}

Ostvariti ekonomski razvoj pogodan za sve stanovnistvo, koji će su₹biti siromastvo $i$ pritom néé ici naustrb prirode i njezinog bogatstva jedan je od primarnih interesa cijelog covječanstva. Ovaj imperativ moguce je ostvariti primjenom principa odř̌ivog razvoja. U ovom tekstu predstavit ćmo uspješan model očuvanja prirodnih resursa tj. odr:̌ivi razvoj iz islamske perspektive. Za primjenu odryivog razvoja bitno je predstaviti tri komponente: ekonomsku (privreda), socijalnu (drustvo) i ekološku (prirodna okolina). Ove tri komponente zasebno su predstavljene kao oblasti islamskog nauka, a zatim ponudena i nj̈hbova uloga u održivom razvoju. Ove naučne discipline koje su razvijene $i$ asimilirane $u$ islamski diskurs fleksibilno $i$ adaptibilno ǔ́estviju u formiranju održivog razvoja. One, iako su zasebne oblasti, kada je održivi razvoj u pitanju povezane su u jednu kohezivnu cjelinu i formulišu djelotvorni koncept odřivog razvoja. Ističemo da se održivi raquoj implementira kroz individualnu i državnu odgovornost.

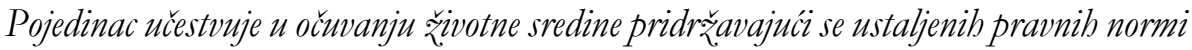
i suzdržavanjem od njenog beskorisnog iskoristavanja, odnosno pridržavajuci se koncepta umjerenosti. Dř̌avna uloga ili političko djelovanje je ižraženiji oblik upravljanja jer vlast regulise odnos i upotrebu prirodnih dobara za stanovnistvo koje se nalazi na datom području propisujuci tom prilikom set ekonomskih mjera. Konstatiramo da je održivi razvoj pronašao svoje mjesto u muslimanskim zemljama u razlicitim formama $i$ da je odr:̌iva arbitektura jedan od ozbiljnijih faktora odr:̌ivog razuoja.

Ključne riječi: održivi razvoj, islamsko ekološko pravo, ekologija, ekonomija $i$ sociologija. 


\section{Uvod}

Održivi razvoj jedan je od najbitnijih segmenata ekološkog djelovanja. Njegovo djelovanje očituje se kroz tri naučne oblasti, odnosno kroz predmete istraživanja tih oblasti: ekonomiju, društvo i okoliš. Tok rada iziskuje puno definicija i objašnjenja pojmova koji su vezani za održivi razvoj. Nakon što smo iskazali osnovne crtice o održivom razvoju i njegovim odrednicima u svjetlu islamskog učenja ukratko smo prikazili ekologiju, ekonomiju i sociologiju iz islamske perspektive. Pokušali smo dati osnovne naznake ovih nauka jer one konstruišu održivi razvoj, ali u svjetlu islamskog učenja kako bismo svaku od njih doveli u sponu s konceptom održivog razvoja iz islamske perspektive. Na kraju smo izložili dva poglavlja koja govore o određenim generalnim naznakama održivog razvoja u muslimanskim zemljama i ulozi arhitekture za održivi razvoj.

Predmet istraživanja ovog rada jeste pojašnjenje uloge islama $u$ stvaranju koncepta održivog razvoja. Hipotezu koju smo postavili, odnosila se na dokazivanje postojanosti održivog razvoja unutar islamskog zakonodavstva, što smo kroz ovaj rad i utvrdili.

Osnovni cilj ovog rada jeste prikazati utemeljenost održivog razvoja unutar islamskog učenja što smo potkrijepili hadisima i govorom islamskih učenjaka i stručnjaka iz oblasti ekologije. Jedan od ciljeva bio je prikazati islamsku viziju zaštite okoliša, upravljanja ekonomijom i društvom, te ih povezati u jednu cjelinu koja će održavati model održivog razvoja. Intencija ovog rada bila je i prikazati jedan od najfrekfentnijih primjera primjene održivog razvoja, a to je arhitektura, kao i prikaz iskustva upravljanja prirodnim resursima unutar određenih muslimanskih zemalja.

Metod kojeg smo primjenjivali u ovom radu oslanjao se na jedan od modela prikazivanja održivog razvoja unutar svjetovne ekologije, a to je pojedinačno prikazivanje osnovnih komponenata održivog razvoja, te njihovo spajanje u kohezivnu cjelinu. Tom prilikom koristili smo se tekstualnom analizom kao i deskriptivnom metodom, predstavljajući tekstove islamskih autora o održivom razvoju. 


\section{Koncept održivog razvoja iz islamske perspektive}

Najpoznatija definicija održivog razvoja jeste definicija komisije koja je zadužena za okoliš i razvoj pri Ujedinjenim nacijama: "Održivi razvoj je razvoj kojim se zadovoljavaju potrebe današnjih naraštaja, a da se pritom ne ugrožava mogućnost budućih naraštaja $u$ zadovoljavanju njihovih potreba."1 Ova definicija odražava i islamsku intenciju definiranja održivog razvoja uz poštivanje islamskih standarda i normi. Arapski naziv za održivi razvoj glasi al-tanmiya almustadāma, dok engleski glasi sustainable development. Ovakav pristup je već prisutan $\mathrm{u}$ islamskom učenju i djelovanju, ali nije definisan na ovakav način, nije zadobio svoju zasebnu formu, niti je razmatran pod posebnom oblašću. Međutim, kada bismo detektirali ovakvu konstalaciju odnosa, došli bismo do zaključka da se održivi razvoj po islamskim standardima očituje u raznim formama i oblicima, kako parcijalnim, pravnim ekološkim normama poput: sađenja sadnica, zabrane zagađivanja javnih i vodenih površina, zabrane mučenja i beskorisnog ubijanja životinja, tako i s općenitim principima poput umjerenosti u konzumiranju prirodnih bogatstava, zabrana ekstravagancije, negativan odnos prema pohlepi i beskorisnom korištenju prirodnih resursa.

S obzirom na to da je održivi razvoj novi koncept kvalitativnog upravljanja prirodnim potencijalima i kao termin stran klasičnom islamskom znanju, njegova prisutnost u savremenom muslimanskom mišljenju artikulira se putem općih islamskih smjernica koje su zasnovane na načelu interesa i preventivnog djelovanja, ali i ostalih izvora islamskog zakonodavstva, kao i fikhskih pravila i intencija šerijata. Ono što se prihvati kao relevantno u islamskom ekološkom pravu, ono se u najvećoj mjeri zasniva upravo na ovim principima, pribavljanju koristi i otklanjanju štete po čitavo čovječanstvo, kao i preventivno djelovanje u suzbijanju potencijalnih štetnih radnji.

Vrijedno je spomenuti da je na Prvoj islamskoj konferenciji ministara okoliša donesena islamska deklaracija "Opći okviri islamske agende o održivom razvoju", a koja je potvrđena na "Svjetskom samitu o

\footnotetext{
1 Dubravka Bačun, Mirjana Matešić i Mislav Ante Omazić, Leksikon održivog razvoja, Hrvatski poslovni savjet za održivi razvoj, Zagreb, 2012., str. 195.
} 
održivom razvoju". ${ }^{2}$ U ovoj agendi postavljeni su slijedeći zadaci: postizanje ekonomskog razvoja koji će zemljama s muslimanskim stanovništvom omogućiti da dostignu ekonomski razvijene zemlje, uravnoteženi odnos između stanovništva i njihovih potreba, suzbijanje siromaštva, uspostavljanje mjere zaštite okoliša pomoću recikliranja otpada i pravilnog odlaganja radioaktivnog i opasnog otpada, izrada studije koja će komparirati ekološku jurisprudenciju unutar muslimanskih zemalja i ostali zadaci. ${ }^{3}$

Značajnu svjetsku pažnju u pogledu održivog razvoja zadobila je AGENDA 21 čije ćemo osnovne zadatke $^{4}$ argumentirati metodologijom islamskog prava.

\section{Suzbijanje siromaštva}

Islamski koncept suzbijanja siromaštva parcijalno će biti predstavljan (u okviru govora o ekonomiji) u nastavku teksta, međutim u kratkim crticama naznačit ćemo osnovne djelatnosti tog koncepta. Potrebno je istaći da islam ima afirmativni stav prema radu, suzbijanju straha od nedolaska nafake, podsticaju na obavezno (u vidu iskupa) i dobrovoljno davanje ishrane siromašnima, davanje različitih materijalnih sredstava onima koji su u potrebi i konačno obavezno izdvajanje dijela imovine koji se naziva zekat. Napominjemo da je za vrijeme pravednog halife Omera b. Abdulaziza siromaštvo $u$ islamskom ummetu bilo iskorijenjeno. Iz državne blagajne uzimao se novac za: otkup robova, vjenčavanje neoženjenih i neudatih, vraćanje dugova, a ono što je posebno interesantno za ekologiju i održivi razvoj jeste podjela sredstava sitnim poljoprivrednicima što je preteča današnjim bankama koje su zadužene za kreditiranje poljoprivrednika. ${ }^{5}$ Takvo blagostanje prenijelo se i na životinje kojima je prosipano žito na mjestima gdje su obitavale.

\footnotetext{
${ }^{2}$ Ovaj samit održan je u Johannesburgu od 26. 8 do 4. 9. 2002. godine.

3 Nedim Begović, Ka islamskom ekološkom pravu, Zbornik radova Fakulteta islamskih nauka, Fakultet islamskih nauka, Sarajevo, br. 12, 2008., str. 175-176.

${ }^{4}$ Zadaci preuzeti iz knjige: Ekonomija i ekologija - održivi razvoj od Bajre Golića, Studentska štamparija Univerziteta u Sarajevu, Sarajevo, 1998., str. 76-81.

${ }^{5}$ Više u: Jusuf Karadavi, Islam i siromaštvo, prijevod: Amrudin Hajrić, prevodilac, Sarajevo, 2003. str. 165-168.
} 


\section{Promjena obrasca potrošnje}

Odgovarajući na ovaj zadatak spominjemo da je islamski nauk usmjeren prema umjerenosti i racionalnom korištenju prirodnih bogatstava. Najviše je to istaknuto u umjerenom konzumiranju ishrane. Period nastanka prvih industrija pa do današnjih dana obilježen je otvaranjem i osnivanjem raznih kako prehrambenih, tako i ostalih industrija koji su ostavili negativan trag na prirodni okoliš. Poštivanje hrane ide i dotle da zalogaj koji čovjeku ispadne, treba da ga očisti i nastavi jesti ${ }^{6} \mathrm{i}$ da se potpunost čovjekovog imana dovodi u pitanje ako njegov komšija zanoći gladan, a on je u mogućnosti da ga nahrani. ${ }^{7}$ Proizvodi različitih vrsta kupuju se radi potrebe i koristi, a ne iz puke želje za njihovim posjedovanjem. Bogataši će kasnije ući u Džennet (što ne znači da će biti na manjem stepenu) u odnosu na siromahe jer moraju položiti račun za njihova bogatstva, što je dodatni motiv za pravilno iskorištavanje imetka. ${ }^{8}$

\section{Zaštita i unapređenje ljudskog zdravlja}

Mnoge savremene bolesti svoje porijeklo imaju u pretjeranoj konzumaciji hrane i s razlogom je rečeno da je pola medicine sažeto u ajetu: "I jedite i pijte samo ne pretjerujte. On, zaista, ne voli one koji pretjeruju", zatim neravnomjernim i brzim načinom života, a rješenje je u poslaničkom konceptu rada i odmaranja, prije ili poslije podnevnog i noćnog odmora. Psihološke probleme musliman otklanja $\mathrm{s}$ vjerovanjem u Božije određenje, namazom, učenjem Kur'ana i slično. Čovjeku se zabranjuje da sebi nanosi štetu bilo koje vrste, a koja narušava njegovo zdravlje. Ima dužnosti koje su vezane za njegovo tijelo što mora da ispoštuje a koje održavaju njegovo tijelo zdravim. U poglavlju koje govori o upravljanju slatkim vodama naveden je argument i propis zabrane sprovođenja kanalizacija naštrub rijeka. Taj propis je povezan i s očuvanjem čovjekovog zdravlja jer takvim

\footnotetext{
${ }^{6}$ Muslim, 2033.

${ }^{7}$ Buhari u Edebul-mufredu, br. 108, str. 55.

${ }^{8}$ Ibn Kajjim el-Dževzijje, Knjiga uputa za strpljive $i$ zahvalne, prijevod: Fahrudin Smailović, Bookline, Sarajevo, 2005. str. 238.

${ }^{9}$ Kur'an, el-A'araf, 31.
} 
postupkom dolazi do širenja raznih štetnih bakterija i pojava zaraznih bolesti i pandemija.

Hadisom u kojem se naređuje pokrivanje vrčeva i posuda s vodom ${ }^{10}$ štiti se voda od doticaja s mikrobima, insektima i prašinom. Slično tome je i ostavljanje vatre da gori, što može dovesti do požara. Pored toga vatrom se oslobađa ugljen monoksid što može izazvati smanjenje nivoa kisika u krvi, a to može dovesti do smrti. U savremenom kontekstu ovakvo nešto događa se puštanjem otrovnih hemikalija koje nastaju uslijed puštanja plina. Također, i gašenje svjetiljki prilikom spavanja sprečava probleme poremećaja hormonalne ravnoteže, a redovnim gašenjem elektronskih uređaja smanjit ćemo opasnost po zdravlje. Buka u okolini ugrožava čovjekovo fizičko i psihičko zdravlje. Ona može oštetiti čovjekov sluh, izazvati česte glavobolje, stres, uzrujanost, narušava uravnoteženi odnos tjelesnih hormona i sl. Preporuka islama, koja je došla sa strane učenja Kur'ana, niti previše glasno, a niti tiho, može biti način i motiv da se radi na rješavanju ovog problema. ${ }^{11}$

\section{Razvoj koncepta održivih naselja}

Razvoj naselja kod muslimanskog življa kreće od građenja molitvenog objekta - džamije iz koje treba da se duhovna i moralna atmosfera prenese na stanovništvo. Snagom duhovnog i moralnog odgoja dešavaju se pozitivne promjene i djelatnosti u društvu. Ovim zadatkom traži se funkcionalno upravljanje društvom bez beskućnika i odbačenih, a što se reguliše međumuslimanskim odnosima i brigom jednih za druge. S društvenom dimenzijom potrebno je zadovoljiti i ekološke standarde mjesta koje naseljava određeno stanovništvo. Nosioci islamske kulture i civilizacije vođeni islamskim napucima življenja uspješno su odgovarali na izazove osnivajući raznovrsne vakufe i putne komunikacije, ali i prilikom ratnih dejstava nisu uništavali prirodna dobra. Odlična alternativa za sveprisutniju masovnu gradnju jeste

\footnotetext{
${ }^{10}$ Buhari, "Zatvaranje vrata noću”, br. 6296; Muslim, "Naredba pokrivanja posuda, vezanje mješina, zatvaranje vrata i pritom spominjanje bismille, kao i gašenje svjetiljki i vatre pri polasku na spavanje i zadržavanje djece i stoke nakon akšam namaza", br. 2012.

${ }^{11}$ Amira Ayad, Zdravlje tijela $i$ duše, prijevod: Derviš Taći i Amir Mehić, Ilum, Bužim, 2012., str. 171-186.
} 
ulaganje u javna dobra koja zadovoljavaju potrebe velikog broja stanovništva. Naprimjer, mnoga poljoprivredna vakufska bogatsva koja su zapuštena i neobrađena mogu biti kultivisana, na kojima bi se proizvodila zdrava hrana, uposlilo domaće stanovništvo i smanjio uticaj industrije na lokalno stanovništvo, a samim tim i zagađeni zrak.

\section{Zaštita atmosfere}

Specifično je da vazdušnu sredinu ugrožava ono što se nalazi i djeluje na kopnu pa je tim putem i treba zaštititi. Očuvanje zraka bez kojeg je nemoguće živjeti spada u jednu od pet nužnih vrijednosti islama, odnosno očuvanje čovjekovog života jer bez zraka nema ni života. Mehanizaciju rješavanja ovih pitanja predočili smo u devetom i desetom zadatku, što ima poveznicu sa zaštitom atmosfere ali i sličnim ekološkim pitanjima.

Nedostatak sunčeve svjetlosti kao i zagađenost zraka izazvani velikim koncentracijama štetnih materija u vazdušnom prostoru štetno djeluju na ljudski razum, raspoloženje i smanjuje njegovu spremnost za realizaciju svakodnevnih poslova. ${ }^{12}$ Velike vrućine izazvane globalnim zatopljenjem, koje je posljedica nemarnog odnosa prema ekološkim standardima, negativno utiču na čovjeka i prirodu.

\section{Održivo upravljanje tlom}

U određenom broju hadisa spominje se i afirmiše bavljenje poljoprivredom kao osnovnom djelatnošću čovjeka na ovom svijetu. Sve biljke koje čovjek konzumira vezane su za tlo, koje se na različite načine metodologijom islamskog prava zaštićuje. Prethodno smo spomenuli poljoprivredu, čemu dodajemo i kultivisanje zapuštenog zemljišta čiji propisi su neizostavan dio knjiga fikha, zatim sađenja sadnica koje je korisno za tlo o čemo ćemo više u narednom zadatku. Ebu Hurejre, r. a., prenosi da je Poslanik, sallallahu alejhi ve sellem, rekao: "Ko ima zemlju, neka je sobom obrađuje ili neka je pokloni

12 Nedim Begović, Ka islamskom ekološkom pravu, Zbornik radova Fakulteta islamskih nauka, br. 12, str. 165. 
svome bratu, pa ako ne prihvati, neka zadrži svoju zemlju (za druge potrebe)!"'13

\section{Sprečavanje odumiranja šuma}

Za ovaj zadatak navest ćemo dva hadisa koji i više nego dovoljno govore o tome koliko islamki nauk pridaje pažnju ovoj djelatnosti. Enes, r. a., prenosi da je Poslanik, sallallahu alejhi ve sellem, rekao: "Nema nijednog muslimana koji zasadi sadnicu ili posije usjev sa kojeg štogod pojede ptica, čovjek ili životinja, a da mu se to sve ne računa posebnom sadakom." "14 Enes, r. a, prenosi da je Poslanik, sallallahu alejhi ve sellem, rekao "Ako nastupi Sudnji dan, a neko od vas bude u ruci imao sadnicu i bude u stanju posaditi je prije nego što on nastupi, neka je posadi." 15

\section{Zaštita i upravljanje slatkim vodama}

Uništavanje slatkih voda biva na način njihovog prekomjernog eksploatisanja ili njihovog zagađivanja. Za prvi način uništavaja slatkih voda spominjemo da se prenosi da je jedne prilike Poslanik, sallallahu alejhi ve sellem, zabranio rasipanje vode na obali rijeke. Zabrana koja se odnosi na drugi dio, odnosno ispuštanja kanalizacije u rijeke i mora, bacanje bilo kakvog otpada u vodene površine, zakopavanje otpada koji je opasan i štetan po podzemne vode, analogno je hadisu u kojem Poslanik, sallallahu alejhi ve sellem, zabranjuje mokrenje u vodu. ${ }^{16}$ Hadisom u kojem Poslanik, sallallahu alejhi ve sellem, ukazuje na tri vrste prokletnika: onih koji vrše velike nužde po vodenim tokovima, putevima i hladovima analogijom se zabranjuje zagađivanje bunareva, rječica, izvora ili neke druge vrste zagađenja javnih površina. ${ }^{17}$

\footnotetext{
13 Buhari,"Drugovi vjerovjesnika, sallallahu alejhi ve sellem, ispomagali su jedni druge oko zasijavanja i plodova”, br. 2342.

14 Buhari, "Drugovi vjerovjesnika, sallallahu alejhi ve sellem, ispomagali su jedni druge oko zasijavanja i plodova", br. 2320.

${ }^{15}$ Buhari u Edebul-mufredu, br. 471, str. 188.

${ }^{16}$ Sulejman Topoljak, Islamski odgovori, el- Kelimeh, Novi Pazar, 2012., str. 338.

${ }^{17}$ Isto, str. 339.
} 


\section{Upravljanje opasnim otpadom}

Cjelokupni islamski diskurs poziva na čistoću i urednost. Otpad treba pravovaljano odlagati na njemu prikladna mjesta, a upravljanje opasnim otpadom u metodologiji islamskog prava mogli bismo svrstati u domen javnog interesa mașlaha mursala ili preventivnog djelovanja sadd al-darāa ' ${ }^{t}$. iznalaženja najboljih rješenja od strane stručnih osoba koje će ujedno biti i efikasne i moralne ili već unaprijed pokušati spriječiti opasni otpad, ali ako to nije moguće onda pokušati ublažiti njegovu prisutnost. Također, ovaj ekološki zadatak moguće je rješavati pomoću različitih fikhskih pravila shodno stanju u kojem se zadese poput: "Nema nanošenje štete niti uzvraćanje štetom"; "Šteta se uklanja"; "Šteta se mora otkloniti u granicama mogućnosti"; "Otklanjanje štete preče je od pridobijanja koristi"; "Veća šteta otklanja se manjom štetom"; "Šteta se ne otklanja istovjetnom štetom"; "U cilju otklanjanja opće, podnosi se personalna šteta." ${ }^{18}$ Također, u elaboraciji ovakvih i sličnih pitanja učestvuju i intencije šerijata tj. zaštita pet temeljnih životnih vrijednosti.

\section{Upravljanje radioaktivnim otpadom}

Izložene stavke u prethodnom zadatku odnose se i na ovaj. Aparati pomoću kojih se reguliše pitanje upravljanja radioaktivnim otpadom svrstava se u domen interesa i preventivnog djelovanja (metodologija islamskogo prava), fikhskih pravila i intencija šerijata.

\section{Islamsko ekološko pravo}

Definicija ekologije glasi: "Ekologija je nauka koja proučava odnose u prirodnim kompleksima živih bića i životne sredine, tj. nauka o uzajamnim odnosima organizama i njihove žive (biotičke) i nežive (abiotičke) okoline". ${ }^{19}$ Ekologija potječe od grčkih riječi oikos (dom, prebivalište) i logos (nauka, znanje, spoznaja).

\footnotetext{
${ }^{18}$ Više u: Osman Kozlić, Fikhska pravila, el-Kalem, Sarajevo, 2005., str. 252-261. i Šukrija Ramić, Opća šerijatskopravna pravila, Islamski pedagoški fakultet i CNS, Zenica, Sarajevo, 2014., str. 61-76.

19 Rifet Škrijelj, Avdo Sofradžija, Esad Maslić, Biologija za četvrti razred opće gimnazije, Svjetlost, Sarajevo, 2001., str. 3.
} 
Islamska ekologija je veoma mlada znanstvena disciplina. Njen sadržaj odlikuje se holističkim pristupom, tj. njeno interesovanje nalazi se $\mathrm{u}$ mnogobrojnim oblastima islamistike poput: hermenautike Kur'ana i hadisa, islamskog prava i vjerovanja, morala, historije islamske kulture i civilizacije, odnosno teologije u njenom punom kapacitetu riječi. Njena sadržina nalazi se unutar svake od ove znanosti, ali sveukupnim prikupljanjem podataka i njihovom obradom ona ima afiniteta da postane zasebna naučna disciplina. Predmet našeg interesovanja $u$ ovom radu je pravna oblast ove nauke, na koju ćemo se i najviše bazirati, ali nije isključeno i spominjanje drugih znanstvenih disciplina vezanih za ekologiju.

$\mathrm{Na}$ osnovu uvida $\mathrm{u}$ prethodno navedene definicije i islamski koncept učenja, nudimo našu definiciju islamske ekologije. Islamska ekologija je nauka koja pomoću općih načela i partikularnih pravnih normi proučava odnos između čovjeka i prirode. Po općim načelima podrazumijevamo načelo tevhida, ihsana, šukra i slično. Pod partikularnim pravnim normama podrazumijevamo već normirana pitanja ili koja su to u mogućnosti poput zabrane mučenja životinja, sađenja sadnica i ostalog. U odnosu na svjetovnu ekologiju, ovdje je iskazana veća pažnja čovjeku, jer je on od Boga odabran da ponese odgovornost (emānet) na Zemlji, ali i održava prirodna bogatstva. Pod prirodom se podrazumijeva i živa (biljke i životinje) i neživa (zemlja, minerali) priroda.

Islamsko zakonodavstvo prepoznaje naziv ekologije kao fiqh al-bì $a h$. Kako smo već razložili riječ ekologija je kovanica od riječi oikos što u potpunosti odgovara riječi $b \vec{l}$ 'ah: stanište, dom, dok za riječ logos čiji bi adekvatniji prijevod, s jezičke strane bio znanje ( ${ }^{\prime} \mathrm{lm}$ ), upotrijebljena je riječ fiqh - razumijevanje. Doslovan prijevod sintagme fiqh al-bì $a h$ označava razumijevanje prirode, što oslikava suštinu praktičnog dijela ekologije. Međutim, u duhu šerijatskopravne nauke ova riječ prevodi se kao islamsko ekološko pravo ili islamska ekološka jurisprudencija.

Izvori islamskog ekološkog pravu su identični s izvorom bilo koje druge pravne nauke, samo što određeni pomoćni izvori više ili manje dolaze do izražaje kod ove nauke u osnovu na druge. 


\section{Islamski standardi ekonomije}

Ostvarenje društvenog blagostanja zavisi od ravnopravne raspodjele prirodnih bogatstava. Bogu pripada apsolutno vlasništvo nad svim, dok je čovjeku dato samo privremeno posjedovanje stvari na ovom svijetu. Čovjek određeni dio imovine u svoj posjed može dobiti preko nasljedstva, kupovine, poklona ili na neki drugi legalan način i to biva njegovo samo dok traje njegov životni vijek. Osnovni princip održivog razvoja u pogledu ekonomije jeste pravilna raspodjela prirodnih bogatstava i smanjenje siromaštva. Jaz između bogatih i siromašnih prema učenju islama premoštava se pomoću nekoliko principa. Težnja ka ostvarenju pravde jedan je od najvećih imperativa kojeg se treba pridržavati u svim aspektima ekonomskog djelovanja. Pravedno (na halal način) steći imetak, znači da taj imetak ne bude zarađen na osnovu kamate, prevare ili uzurpacijom tuđeg posjeda ili imetka. No, to nije dovoljno zarad blagostanja čitavog društva, jer ima nemoćnih, bolesnih i siromašnih koji ne mogu doći do osnovnih sredstava za život. Gospodar je vjernicima propisao davanje zekata pod određenim uvjetima, što predstavlja osnovni mehanizam u suzbijanu siromaštva. Pored toga, za određene prekršaje ili vidove iskupa Gospodar je propisao da se daje otkup, najčešće u vidu hrane. Pored ovih strogih obaveza, u islamskom zakonodavstvu podstiče se na dobrovoljno davanje imetka u raznovrsnim formama.

\section{Sociološki nauk islama}

Neupitna je konstatacija da islam nudi rješenje za sve fenomene i pojave, međutim oni se ne mogu sami od sebe elaborirati i sistematizirati. Izvori islama sadrže zdrave temelje i mehanizme sociološke nauke. Razvoj društva, njegovo djelovanje i procese koji se unutar njega dešavaju objasnio je čuveni islamski sociolog i preteča savremene nauke sociologije Ibn Haldun. Kao definiciju sociologije navodimo da je to: "posebna društvena nauka, koja za predmet svog izučavanja ima međuljudske odnose, društvo u njegovoj cjelini, opća zajednička obilježja svih društvenih pojava kako u strukturalnom, tako i u razvojnom vidu"20

${ }^{20}$ Esmir Halilović, Socijalna učenja islama, autor, Zenica, 2019., str. 19. 
Gustina naseljenosti utječe na ekonomski, politički i socijalni status određenog područja. Na osnovu rasta stanovništva treba se i osigurati ekonomski balans između potreba stanovništva i kapaciteta prirodnih dobara. Tomas Maltus zastupao je teoriju da stanovništvo treba pomoću raznih načina (rat, bolest) smanjiti, jer u budućnosti neće biti dovoljno sredstava za životno izdržavanje. ${ }^{21}$ Ova teorija je u suprotnosti sa šerijatom. Preporuka Poslanik, sallallahu alejhi ve sellem, njegovim sljedbenicima je da rađaju potomke, jer će se on ponositi s njihovom brojnošću na Sudnjem danu. Svakom čovjeku propisana je nafaka, o čemu nam svjedoči hadis u kojem se spominje da prije udahnuća duše, melek zapiše četiri stvari: nafaku, dužinu života, djela, i da li će biti od sretanih ili nesretanih. ${ }^{22}$ Svaki čovjek, bio on musliman ili ne, njemu je propisano tačno određena količina hrane koju će za života potrošiti.

\section{Opći principi islamskog koncepta održivog razvoja}

U nastavku ćemo analizirati dva teksta u kojima se govori o općenitim principima održivog razvoja. Muhammed Nuh u tekstu Sustainable development in a muslim context (Održivi razvoj u muslimanskom kontekstu) povezuje ciljeve održivog razvoja s ciljevima islama, koji pozivaju na izbjegavanje gomilanja prekomjernog otpada, monopola nad resursima i korupcije. Pravilno upravljanje resursima podrazumijeva: održavanje ukupne ravnoteže s okolinom, osiguravanje opstanka svih vrsta, konzumiranje iz prirode u mjeri koja je dovoljna, izbjegavanje rasipanja i optimalno korištenje resursa.

Resursi se, prema ovom autoru, moraju čuvati i zaštititi od zagađenja, otpada i prekomjerne eksploatacije kako bi ih iduće generacije mogle koristiti. Autor je spomenuo nekoliko fikhskih pravila koje je potrebno inkorporirati u sistem islamskog održivog razvoja: "Nema nanošenja štete", "Šteta se otklanja", "Otklanjanju štete daje se prednost nad pribavljanjem koristi”, "Osobna šteta trpi se zarad zajedničke štete”. Na

${ }^{21}$ Husein Đozo, Kontrola i planiranje rađanja u svjetlu učenja islama, Savremene fikhske teme, priredio: Enes Ljevaković, Fakultet islamskih nauka, Sarajevo, 2006., str. 170 .

22 Buhari, Sahih, "Spominjanje meleka”, br. 3208; Muslim, Sahih, "O tome kako se u utrobi majke stvara čovjek, kako se bilježe njegova nafaka, djela i smrtni čas, te da li će biti sretan ili nesretan", br. 2643. 
osnovu ovoga svako ekološko pravo, povlači za sobom i obavezu, čovjek smije koristiti vodu, ali ne smije da je zagađuje i ne smije se otpad odlagati u okeane $\mathrm{i}$ druge vode. ${ }^{23}$ Islam na ovu vrstu propusta gleda kao na prekršaj s pravnog i grijeh s moralnog aspekta.

U nastavku predstavit ćemo pravne i moralne principe po kojem bi se trebao tretirati održivi razvoj. Na osnovu spomenutih principa postiže se korist, ostvaruje se interes i preventivno djeluje protiv svih negativnih uticaja na planeti Zemlji. Što se tiče moralnih principa, oni su predstavljeni u obliku namjesništva i uravnoteženosti. Namjesnik preuzima na sebe odgovornost da kontinuirano održava blagostanje za sve ljude. Uravnoteženost se ogleda u ravnopravnom odnosu između dunjaluka i ahireta. Vjera se mora aktivno primjenjivati, kako na duhovnoj, tako i na materijalnoj dimenziji. Moralni principi se ogledaju u: svjedočenju Božije jednoće, zahvalnosti, strpljivosti, spominjanju Allaha, spoznaji i pravdi. Ove pojmove potrebno je da svaki pojedinac pravilno percipira i da mu oni budu vodilja za odgovoran način života spram Gospodara i okoline. Pomoću zahvalnog odnosa naspram blagodati koje dobiva, on će ih poštivati i neće težiti ka ekonomskom iskorištavanju i sebičnom profitiranju. Čovjeku je potrebna određena doza strpljivosti da na racionalan način iskorištava prirodne resurse $\mathrm{i}$ crpi njihove koristi. Pritom će se osloniti na Uzvišenog Allaha i pravedno djelovati prema ostalim Božijim stvorenjima.

Islamski koncept održivog razvoja znači kreiranje boljeg života, obezbjeđujući svima osnovne životne potrebe, koje ne smije ići po svaku cijenu, odnosno ostvarivanja zabranjenog profita. Svaki čovjek mora kontinuirano poštovati Božije upute i voditi se gore spomenutim principima. Sve je stvoreno sa svrhom i u tom pravcu se mora $\mathrm{i}$ djelovati. Djelovanje u pravcu održivog razvoja je djelovanje u pravcu koncepta fitre - prirodne paradigme Božijeg stvaranja. ${ }^{24}$

\footnotetext{
${ }^{23}$ Muhammed Nuh, Sustainable development in a muslim context (Održivi razvoj u muslimanskom kontekstu) Exploring Synergies between Faith Values and Education for Sustainable Development, 2012., str. 39-44.

${ }^{24}$ Hamdan Aziz, Sustainable development from islamic perspective, (Održivi razvoj iz islamske perspektive), International Journal of Civil Engineering and Technology (IJCIET), Palavakkam, 2018.
} 


\section{Ekonomska dimenzija održivog razvoja}

Ekonomija treba da osigura dostojanstven život za sve članove društva, da uspostavi socijalnu pravdu i održi ekonomsku ravnotežu među svim građanima. Ekonomija se u islamskom zakonodavstvu može definira kao uravnoteženo i trajno poboljšanje materijalne i nematerijalne dobrobiti čovjeka, ${ }^{25}$ a što nam omogućava lakše razumijevanje odnosa ekonomije i okoliša. Ekonomski razvoj predstavlja višedimenzionalni proces koji uključuje poboljšanje blagostanja kroz napredovanje, reorganizaciju i distribuciju dobiti u skladu s islamskim učenjima. Među komponente takvog odnosa spada i reguliranje cijena od strane vlade kada to potrebe zahtijevaju (u vanrednim okolnosti tj. kada stanovništvo tim potezom biva oštećeno) u suprotnom reguliranje cijena je prepušteno ljudima (trgovcima). ${ }^{26}$ Državni službenici treba da se savjetuju s različitim stručnjacima iz oblasti kako bi se postigao što bolji ekonomski, socijalni i okolišni efekt. Potrebe ljudi i lokalne zajednice na kojoj obitavaju razlikuju se shodno okolnosti u kojima se nalaze. Na tragu ovoga osnovano je i Nacionalno ekonomsko savjetodavno vijeće (eng. NEAC). ${ }^{27}$ Ovo vijeće podjednako uvažava mišljenje stručnjaka i lokalnog stanovništva.

Ekonomski razvoj mora popratiti i društveno-politička održivost, odnosno zadovoljavajuću raspodjelu dohodaka. Islam podržava holistički pristup održivog razvoja. Sve društvene, ekonomske i

https://www.researchgate.net/publication/325100693_Sustainable_development from_islamic_perspective, pristupljeno 19.5. 2020.

${ }^{25}$ Patmawati Ibrahim, Asmak Abdu-Rahman i Siti Arni Basir, Sustainable economic development: concept principles and management from islamic perspective, (Održivi ekonomski razvoj: koncept, principi i poslovanje sa islamske perspektive), European Journal of Social Sciences, 2010.

https://www.researchgate.net/publication/277200174_Sustainable_Economic_Devel opment_Concept_Principles_and_Management_from_Islamic_Perspective, pristupljeno: $19 . \overline{5} .2020$.

${ }^{26}$ Više o ovoj temi u: Abdulaziz Islahi, Ibn Teymiyyina ekonomska misao, prijevod: Džana Avdagić, Almedina Avdić, Amina Džaferovićm Resul Mehmedović , Udruženja građana "Multi", Tuzla, 2018., str. 117-124. Hanefijski stručnjaci smatraju da je dozvoljeno regulirati cijene kada su ljudi oštećeni njenim povećanjem.

${ }^{27}$ National Economic Advisory Council (NEAC) nalazi se u Maleziji. Osnovano je s ciljem poboljšanja ekonomske siituacije u Maleziji. Ovo vijeće je pod ingerencijom premijera i sastoji se od jedanaest stručnjaka za ekonomska pitanja. 
ekološke elemente je potrebno sagledati i donijeti konačni sud o određenom pitanju. Jedno od obilježja održivog razvoja jeste minimiziranje potrošnje. To je moguće postići na osnovu dobrovoljnog odricanja (koje je u islamu poželjno i čime se odgaja čovjekova duša) i zabranom ekstravagancije. ${ }^{28}$

$\mathrm{U}$ knjizi Islamic perspectives on sustainable development (Islamska perspektiva održivog razvoja) na prvim stranicama predstavljena su mišljenja islamskih mislilaca o održivom razvoju, a zatim je autor ponudio i sopstveni model održivog razvoja. Treba se, prema mišljenju autora, na pravilan način regulirati i odvojiti privatno od državnog vlasništva. Autor je naveo šest principa u kojima se očituje interes očuvanja okoliša i preventivno djelovanje protiv njegovog prekomjernog iskorištavanja ili zloupotrebe: Allah je vlasnik svega; Zloupotreba prava je zabranjena; Postoje prava koja su zajednička i koja se ostvaruju određenim ulaganjima; Ako dođe do nestašice resursa onda se kontrolišu; Opće dobro je zaštićeno; Korist je zaštićena, a štete treba da se uklone ili umanje. ${ }^{29}$

Održivi razvoj mora se sagledati u svjetlu iznalaženja pravovaljanih rješenja, potrošnje resursa, distribuciji otpada i onečišćenja koje je prisutno u naseljenim područjima. Potrebno je razviti set strategija kako bi se postigao održivi razvoj, među njima je i dugoročno ulaganje koje daje bolje rezultate i izravno utiče na finansijsku uspješnost. Uloga islamske ekonomije je veoma važan aspekt za pribavljanje koristi koja se odražava naspram održivog razvoja, te preventivno djeluje u suzbijanju siromaštva. Ukidanjem kamate i zelenaštva zaštitila bi se hegemonija bogatih i njihovo bogaćenje nad siromašnima. Potrebno je uz duhovni razvoj uskladiti slijedeće elemente kako bi održivi razvoj postigao svoj cilj: socio-kulturne, ekonomske, političke i pritom zaštititi okoliš, odnosno živjeti u kapacitetu s kojim raspolaže planeta Zemlja. Pored zagovaranja islamske beskamatne ekonomije potrebno je i tu ekonomiju koristiti u određenim kapacitetima kako bi se interes cijelog

\footnotetext{
${ }^{28}$ Iz prethodno citiranog članka.

${ }^{29}$ Atih Roheaeti Dariah, The shape of islamic sustainable development, (Oblik islamskog održivog razvoja) Islamic perspectives on sustainable development Urednici: Shereeza Mohamed Saniff Raudha Md Ramli, Centre for Islamic Development Management Studies (ISDEV) i Islamic Relief Academy, Malezija, 2016., str. 1-12.
} 
čovječanstva zaštitio. ${ }^{30}$ Alternativa je u islamskoj ekonomiji i ostvarivanju profita na osnovu proizvoda, a ne na osnovu novca.

\section{Socijalna komponenta održivog razvoja}

Socijalno djelovanje treba ići ka ostvarivanju jedne kohezivne cjeline, kako na pojedinačnom tako i na društvenom planu, međusobno se dogovarati i značajnije uspostaviti institucije zekata i vakufa kako bi se siromaštvo suzbilo u cijelosti. ${ }^{31}$

Velike potrebe, porast stanovništva, nepravilna i neravnomjerna raspodjela prirodnih dobara dovele su do strašne devastacije okoliša, ozonskog iscrpljenja, topljenja ledenih površina, globalnog zagrijavanja $\mathrm{i}$ enormne sječe šumskih površina. $U$ vezi $\mathrm{s}$ ovim konceptom, iako nije dovoljno razvijen po islamskim standardima, postoje univerzalne smjernice po kojima treba djelovati. U takve smjernice spada princip da nema nanošenja štete, niti uzvraćati na istu, da pohlepu treba sputavati, umjereno koristiti resurse i održavati ravnotežu.

Potrebno je djelovati u tri najvažnija smjera koja su zajednička poveznica ekonomije i ekologije, a u interesu su sadašnjih i budućih generacija:

1. Održavanje dugoročne stope ekonomskog rasta;

2. Postizanje transgeneracijske jednakosti $\mathrm{u}$ iskorištenju prirodnih resursa;

3. Sprečavanje zagađenja prirodnog okoliša.

Sve veći jaz između bogatih i siromašnih potrebno je smanjiti. Ne bi smjelo da se desi da potrebe jednog stanovnika neke bogate države odgovaraju potrebama čitavog područja u nekoj siromašnoj državi.

${ }^{30}$ Mohammed Rizki Moi, Muhammad Hakimi Mohd Shafiai i Bayu Taufiq Possumah, Concept of sustainable development from islamic perspective, (Koncept održivog razvoja iz islamske perspektive) The 3rd International Conference of Management and Muamalah 2016. Thailand, 2016., str. 221-226.

${ }^{31}$ Hamida Aborounia i Martin Sexton, Islam and sustainable development, (Islam i održivi razvoj) Third International Built and Human Environment Research Week, Rotterdam, 2006. http://www.irbnet.de/daten/iconda/CIB9051.pdf, pristupljeno 21. 5. 2020. 
Nepridržavanje zakona koji reguliraju ekološko djelovanje i nedostatak odlučnosti za provođenjem zakona je veliki problem koji treba biti prevaziđen. Za resurse, koje zajednički koristi više država, potrebni su međunarodni sporazumi kako bi se prema tim resursima racionalno odnosili (npr. rijeke). ${ }^{32}$

Vakuf i zekat kao dvije islamske finansijske institucije mogu igrati značajnu ulogu u suzbijanju siromaštva. Njih spominjemo u socijalnoj komponenti jer one nemaju isti status kao ekonomsko djelovanje. Neodvojive su od takvog načina rada, ali njihova intencija nije samo profit već i suzbijanje siromaštva, balansiranje socioloških razlika, pomaganje i suosjećanje s drugima i umiljavanje Bogu. Zekat se djeli u jednu od osam, Kur'anom spomenutih kasa, koji ne samo da poboljšava socijalni status društva već učestvuje i suzbijanju enormnog bogaćenja pojedinaca. Islam nema negativan stav prema bogatstvu, dapače podstiče i ukazuje da je gornja ruka bolja od donje, ali to bogatstvo ima svoje principe i granice. Vakuf koji je na manjem stepenu pravnog normiranja u odnosu na zekat, ima širi spektar socio-ekološkog djelovanja. Kroz generacije vakuf se osnivao u različite svrhe i za različite potrebe. Možemo istaći slijedeće vakufe u kojima se prožimaju socijalne i ekološke koristi: vodosnadbjevanje, infrastruktura, kultivisanje zemljišta i sađenje sadnica, zaštita životne sredine i zaštita životinjskog svijeta. Primjeri za te vakufe su: sebilji, javna kupatila, voćnjaci, poljoprivredni posjedi, botanički vrtovi, vakufi za ishranu životinja i slično. ${ }^{33}$

\section{Ekološka komponenta održivog razvoja}

Prirodni okoliš je mjesto pomoću kojeg se može doći do enormnih bogatstava. Pretjerana upotreba bilo kojeg resursa može dovesti do njenog istrebljenja. Mnogi resursi koji su u stalnoj upotrebi, ograničenog su kapaciteta te je jedino rješenje njihovo racionalno

\footnotetext{
${ }^{32}$ Zubeir Hasan, Sustainable development from an Islamic Perspective: meaning implications andpolicy concerns, (Održivi razvoj iz islamske perspektive: značenje, implikacije i politička dimenzija) JKAU: Islamic Economics, Malezija, 2006., str. 318.

${ }^{33}$ Zgodno je spomenuti i naučno-stručni skup s međunarodnim učešćem održanom u Zenici, a koji govori o socijalnom aspketu vakufa pri čemu je pripremljen i zbornik radova.
} 
korištenje i traganje za zamjenskim izvorima energije. Glavne posljedice uništavanja prirode su redukcija ili nestanak velikog broja bioloških vrsta, nestajanje i erozija tla, te smanjeni udio tropskih kiša u proizvodnji kisika na svjetskom nivou. ${ }^{34}$

Ukratko ćemo predstaviti islamski princip umjerenosti, pomoću kojeg je moguće zaštititi okoliš. Umjerenost u svim aspektima života, pa i u konzumiranju, nužnih i poželjnih potreba je jedna od najvažnijih maksima islama. Allah u Kur'anu naređuje da se ne pretjeruje s unosom u organizam hrane i pića, a Poslanik, sallallahu alejhi ve sellem, u hadisu pojašnjava u kojoj mjeri: nekoliko zalogaja koji bi držali čovjeka u dobrom zdravlju, a ako mu je potrebno i više od toga neka onda jednu trećinu stomaka napuni hranom, drugu vodom, a treću ostavi praznu. ${ }^{35}$ Pretilost i gojaznost danas je uzrokom mnogih bolesti. Velike količine prirodnih bogatstava, poput vode troše se kako bi se zgotovile različite vrste hrane, slatkiša, sokova i sve to kako bi zadovoljilo, ne potrebe, već želje za nečim novim i drugačijim od prethodnog. Umjerenost se treba projicirati i na druge segmente konzumerizma, poput: odjeće, obuće, kućnih stvari, ukrasa i ostalog. Ovaj princip ima najveći uticaj na smanjenje potrošnje prirodnih resursa.

\section{Primjena održivog razvoja u muslimanskim zemljama}

Iz navedenih modela održivog razvoja u muslimanskim državama moguće je zaključiti kako su islamski principi pridodani konceptu održivog razvoja. Održivi razvoj mora ići u smjeru poboljšanja upravljanja ljudskih resursa, osiguranja osnovnih namirnica koje bi zadovoljile potrebe i poboljšale kvalitet života, smanjile ekonomske i socijalne nejednakosti, razvile nove tehnologije koje su prilagođene domaćem tržištu, koje će osnažiti domaću proizvodnju i neovisnosti od međunarodnog tržišta. Sve ono što će pridonijeti blagostanju društva i neće remetiti kvalitet prirode treba i usvojiti. S koje god strane da dođe prihvatljivo rješenje potrebno ga je inkorporirati u islamske principe.

\footnotetext{
${ }^{34}$ Diana Garašić, Uvodno o održivom razvoju, Obrazovanje za održivi razvoj, urednik: Miroslav Mićanović, Agencija za odgoj i obrazovanje, Zagreb, 2011., str. 15. ${ }^{35}$ Tirmizi, "O pokuđenosti pretjerivanja u jelu" br. 2502. Šejh Albani ovaj je hadis ocijenio vjerodostojnim.
} 
Potrebno je premostiti jaz između štednje i ulaganja, kao i izvoza i uvoza robe. Islamski obrazac trošenja poziva na štednju resursa što dovodi do realizacije interesa njihovog očuvanja. Prirodni resursi koji su u državnom vlasništvu trebaju se usmjeriti ka ostvarivanju koristi društva.

Pored toga, da bi se ostvarilo blagostanje društva potrebno je osigurati bankarske olakšice kojima u prvom planu neće biti interesi pojedinaca, već kolektivne zajednice. Za održavanje stalne stope rasta potrebno je proširiti domaće kapacitete resursa i proizvodnje. Muslimanske zemlje moraju se okrenuti ka lokalnoj proizvodnji, koja bi trebala biti glavni izvor njenog razvoja. $U$ tom smislu je potrebna i međumuslimanska saradnja i smanjenje ovisnosti od drugih sistema. Za poljoprivredni razvoj određenog područja potrebno je obezbijediti zemljište, opremu i ljudski potencijal. Moguće je i iskoristiti institucionalno izdvajanje zekata siromašnom stanovništvu u vidu dodjeljivanja opreme za poljoprivredu, stoku, poljoprivrednu mehanizaciju i slično.

Neki od primjera uspješnog djelovanja u muslimanskim državama su: primjer Alžira i uspjeh u razvoju sorti sjemena za kultiviranje zemljišta, primjer iskorištavanja solarne energije u zemljama centralne Azije, kao i iskorištenost umjetnih jezera za uzgoj ribe i škampe ili eksperimenti nigerijskih farmera koji se sastoje od poticanja termičkog omekšavanja tvrdog tla kako bi u njih kiša dosegla i kako bi se iskoristilo za sjetvu. Potrebno je ostvariti jasnu dugoročnu politiku obradivog zemljišta.

Od pitanja koja mogu ići u prilog ovoj temi jeste i uloga vakufa. Vakufom se mogu regulirati koristi koje su od općeg interesa svih građana, a sve to bi trebalo transparentno raditi, kako bi se korist od prihoda vakufa očitovala na više nivoa. Primjer kako djelovati u tom pravcu je omogućavanje pitke vode za sve stanovništvo, posebno siromašni sloj.

Model inspektorata - javnog nadzora moguće je iskoristiti u principu održivog razvoja, tako što će se učvrstiti halal i pravedno tržište, a otkloniti štete koje se javljaju u korumpiranim i nepravednim društvima. Institucionalni doprinos za održivi razvoj očituje se u provođenju potpisanih ugovora, iskorjenjivanju korupcije, omogućavanju napredovanja ljudskih kapitala, pribavljanju sredstava za javni interes građana, poboljšanju rada tržišta, povećanju 
produktivnosti i rasta proizvodnje, promjeni procesa potrošnje i ponašanja potrošača. ${ }^{36}$

\section{Značaj arhitekture za koncept održivog razvoja}

Koristi održive arhitekture odražavaju se kroz nekoliko nivoa: korištenje lokalnog građevinskog materijala, optimizacija kišnice i optimiziranje sunčeve svjetlosti. Korištenje lokalnog materijala utiče na ekonomiju zajednice, smanjuje se nivo ugljika koji je posljedica upotrebe i prijevoza materijala s drugog mjesta.

Sakupljanjem i upotrebom kišnice pomaže u očuvanju kapaciteta voda koje dolaze iz rijeka i potoka. Proces dovođenja vode u zgradu, objekte povećava troškove i smanjuje prirodne resurse. Kišnica se može upotrijebiti za: kupanje, ličnu higijenu, pranje vozila, kuhinjske namjene, zalijevanje biljaka, a time bi se uštedjela pitka voda. Šteta je da se ne iskoristi ovaj prirodni resurs. Sunce je prirodni izvor koji je nedovoljno iskorišten. Njegova upotreba može zamijeniti vještačku upotrebu energije u kojoj se troše fosilna goriva da bi se pokrenule mašine elektrodistribucije. Također, sunčeva svjetlost može služiti kao alternativni izvor energije. Upotrebom solarne ploče čuva se energija koja se kasnije može iskoristiti za energetsku potrošnju. Optimizacija sunčeve energije, arhitektonski gledano, može se postići pravljenjem većih otvora na objektu, boljim rasporedom i planiranjem unutrašnjeg dvorišta. Postojanje vrta u dvorištu, arhitekturskih otoka, doprinosi povećanju količine kisika u zraku što utječe na čovjekovo zdravlje, mjesto je za mnoge insekte, lijep je ambijent za druženja i doprinosi psihološkom smiraju. U ovakvom vrtu mogu se zasaditi raznovrsne biljke, što doprinosi njihovom očuvanju. Indonezija je primjer muslimanske države koja je usvojila određene principe ekološki održive arhitekture. To uključuje korištenje ekološkog i lokalnog materijala. Zgrade posjeduju objekt za iskoristivo korištenje vode, skupljanje kišnice, prečišćavanje otpadnih voda, sistem za cirkuliranje

\footnotetext{
${ }^{36}$ Monzer Kahf, Sustainable development in the muslim countries, (Održivi razvoj $u$ muslimanskim državama) bez izdavača i mjesta izdavanja, 2002., str. 1-66.
} 
zraka, kao i maksimalno iskorištavanje sunčeve svjetlosti. Također, u zgrade se uključuje i posjedovanje "biljne infrastrukture". ${ }^{37}$

\section{Zaključak}

Osnove za održivi razvoj pored toga što pronalazimo u osnovi islamskog koncepta i načina djelovanja, potvrđujemo i postojanost argumenata iz glavnih izvora islama. Ona pitanja koja direktno nisu spomenuta $u$ tekstu, rješavaju se pomoću ostalih izvora razrađenih $u$ metodologiji islamskog prava poput: analogije, javnog interesa, preventivnog djelovanja i slično, kao i fikhskih pravila i intencija šerijata. Fleksibilnost i adaptilnost islamskog prava prava je "šteta" ne iskoristiti za definisanje i praktičnu razradu ekoloških modusa, među kojima je i održivi razvoj. Doprinos razvoja ovog modela treba biti na individualnoj, kolektivnoj i stručnoj odgovornosti. Islamski pravnici i stručnjaci ekološkog prava (a poželjno bi bilo da se to spoji u jednu osobu) teoretski mogu razraditi mnoga pitanja. Međutim, ako oni ne pronađu svoju praktičnu sprovedbu, kako od vlasti tako i naroda, to će ostati suho slovo na papiru. Muslimanske zemlje sa svojom raznolikošću u prirodnim bogatstvima (od Istoka do Zapada) imaju afiniteta da ponude globalna ekološka rješenja. Nažalost, nismo uspjeli da izbjegnemo korištenje prefiksa islamski ili spominjanje iz islamske perspektive iako imamo afiniteta da ponudimo globalna rješenja za ekološke probleme. Održivi razvoj i ekologija nisu ništa drugo nego dio islamskog učenja koji nije dovoljno razrađen. Čak i kada bismo uspjeli na tom planu, potrebno je mnogo rada i truda da se nametnemo na svjetskoj sceni i da budemo lideri u očuvanju planete Zemlje za koju je Poslanik, sallallahu alejhi ve sellem, izjavio da je čitavim svojim prostorom mjesto za obavljanje molitve tj. mesdžid.

Kao neke od zaključaka koje bi trebale biti polazna osnova za razvoj koncepta islamskog održivog razvoja navodimo slijedeće:

1. Održivi razvoj predstavlja jedan od najboljih modela racionalnog korištenja prirodnih resursa. Pronalazak najadekvatnijih rješenja na relaciji priroda, ekonomija i stanovništvo, produkt je fleksibilne

\footnotetext{
37 Maysarah Binti Bakri, Sustainable architecture through islamic perspective, (Održiva arhitektura kroz islamsku perspektivu) Conference Proceedings - ARICIS I, Indonezija, 2016., str. 491-499.
} 
uloge interesa i preventivnog djelovanja. Racionalna iskoristivost resursa i njihova zaštita za buduće generacije očituje se u primjeni interesa i preventivnom uklanjanju potencijalne štete.

2. Pored postojećih, potrebno je napisati i nove studije, stručne radove i ostale vidove pismenog traga uvažavajući novonastale ekološke probleme kako bi se pobliže odredio status održivog razvoja iz islamskog domena te ponudila konkretna rješenja za njegovo sprovođenje.

3. Sadržaj naučnih radova mora dobiti praktični značaj. Vlast koja je vođena islamskim principima mora aktualizirati pitanje održivog razvoja, otvoriti posebne urede koji će biti zaduženi za ovu problematiku te zakone usmjeriti ka ostavaranju koncepta održivog razvoja.

4. Ekonomiju treba usmjeriti ka stvarnim potrebama, a ne da bude usmjerena prema ostvarenju što većeg profita.

5. Iz okoliša treba uzimati onoliko koliko ga je moguće nadoknaditi i koliko to faktičke i realne potrebe zahtijevaju.

6. Potrebno je zadovoljiti socijalnu pravdu među ljudima, uvažavajući principe i standarde koje Kur'an i sunnet nalažu, što rezultira iskorjenjavanju siromaštva. Uzvišeni Allah stvorio je dovoljno resursa za potrebe svih stanovnika, samo ako se oni racionalno koriste.

7. Održivi razvoj treba usmjeriti ka očuvanju čovjekovog zdravlja putem afirmisanja i pomaganja industrija i lokalnih proizvođača zdrave hrane i nametanja uslova koji se moraju ispuniti da bi se hrana mogla proizvoditi.

8. Manje privrednike različitih profila potrebno je finansijski podržati od strane države. To omogućava da se koristi lokalni materijal i umanjuje uvoz strane robe $u$ koju se ulažu dodatna sredstva transporta što pridonosi zagađenju vazduha.

9. Afirmisati i potpomagati sadnju biljnih kultura, osnivanje fondova za zaštitu šuma i sadnju sadnica, te iskorištavanje zemljišta u poljoprivredne svrhe. Na ovakav način se zemljište čuva od propadanja i bivanja neplodnim. 
10. Postaviti uslove industrijama kako njihov rad ne bi zagađivao čist vazduh. To se može učiniti obaveznim nametanjem upotrebe filtera za pročišćavanje negativnih gasova ili obaveznom upotrebom ekološki prihvatljivog materijala.

11. Kanalizacije i druge oblike štetnih materija moraju se odvojiti od vodenih površina, te ih je potrebno pravovaljano regulisati.

12. Potrebno je preventivno djelovati protiv stvaranja ogromnih količina otpada, a posebno opasnog otpada. Rješenje je u proizvodnji materijala od obnovljivih resursa, njihovom umjerenom konzumiranju, zatim recikliranju, a moguće je uvesti i određene mjere štednje koje neće ugrožavati normalan protok života.

13. Iskoristiti iskustva različitih zemalja u njihovoj nakani da se očuva životna sredina, te ih pravovaljano implementirati u svojoj državi.

14. Za izgradnju različitih vrsti objekata korisititi što više lokalnog i ekološkog materijala. Usvojiti obrasce i standarde u arhitekturi koji se moraju ispoštovati prilikom gradnje novih objekata. Zaštititi područja od ekološkog značaja, tako što će se na tim mjestima zabraniti gradnja.

15. Iskoristiti zapuštene vakufske parcele u očuvanju prirodnih dobara sadnjom sadnica i bavljenjem poljoprivredom što će rezultirati ekološku, ekonomsku i socijalnu dobit.

\section{Korištena literatura}

\section{Knjige:}

Alajbegović, Izudin, (2015) Skraćeni komentar Tirmizijeve zbirke hadisa (uz ocjene šejha Albanija, rhm.), Off-set, Tuzla.

Ayad, Amira, (2012) Zdravlje tijela i duše, prijevod: Derviš Taći i Amir Mehić, Ilum, Bužim.

Buhari, Muhammed b. Ismail, (2008) Buharijeva zbirka hadisa, prijevod: Hasan Škapur, (...), Visoki saudijski komitet za pomoć BiH, Sarajevo.

Buhari, Muhammed b. Ismail, (2009) Knjiga o edebu, prijevod: Armin Abaza, Karađoz grupa, Mostar. 
Dubravka Bačun, Mirjana Matešić i Mislav Ante Omazić, (2012) Leksikon održivog razvoja, Hrvatski poslovni savjet za održivi razvoj, Zagreb.

el-Dževzijje, Ibn Kajjim, (2005) Knjiga uputa za strpljive i zahvalne, prijevod: Fahrudin Smailović, Bookline, Sarajevo.

Golić, Bajro, (1998) Ekonomija i ekologija - održivi razvoj, Studentska štamparija Univerziteta u Sarajevu, Sarajevo.

Halilović, Esmir, (2019) Socijalna učenja islama, autor, Zenica.

Islahi, Abdulaziz, Ibn Teymiyyina ekonomska misao, prijevod: Džana Avdagić, Almedina Avdić, Amina Džaferovićm Resul Mehmedović , (2018) Udruženja građana "Multi“, Tuzla.

Karadavi, Jusuf, (2003) Islam i siromaštvo, prijevod: Amrudin Hajrić, prevodilac, Sarajevo.

Kahf, Monzer, (2002) Sustainable development in the muslim countries, bez izdavača i mjesta izdavanja.

Kozlić, Osman, (2005) Fikhska pravila, el-Kalem, Sarajevo.

Kušejri, Muslim b. Hadždžadž, (2015) Muslimova zbirka hadisa, prijevod: Šefik Kurdić i Semir Rebronja, Islamski pedagoški fakultet Univerziteta u Zenici i Centar za proučavanje orijentalne civilizacije i kulture, Zenica Novi Pazar.

Obrazovanje za održivi razvoj, (2011) urednik: Miroslav Mićanović, Agencija za odgoj i obrazovanje, Zagreb.

Ramić, Šukrija, (2014) Opća šerijatskopravna pravila, Islamski pedagoški fakultet i CNS, Zenica, Sarajevo.

Savremene fikhske teme, (2006) priredio: Enes Ljevaković, Fakultet islamskih nauka, Sarajevo.

Škrijelj, Rifet, Sofradžija, Avdo, Maslić, Esad, (2001) Biologija za četvrti razred opće gimnazije, Svjetlost, Sarajevo.

Topoljak, Sulejman, (2012) Islamski odgovori, el- Kelimeh, Novi Pazar.

\section{Članci:}

Aborounia, Hamida i Sexton, Martin, "Islam and sustainable development", Third International Built and Human Environment Research Week, Rotterdam, 2006. 
Aziz, Hamdan, "Sustainable development from islamic perspective", International Journal of Civil Engineering and Technology (IJCIET), Palavakkam, 2018.

Bakri, Maysarah Binti, "Sustainable architecture through islamic perspective", Conference Proceedings - ARICIS I, Indonezija, 2016.

Begović, Nedim, "Ka islamskom ekološkom pravu", Zbornik radova Fakulteta islamskih nauka, Fakultet islamskih nauka, Sarajevo, br. 12, 2008.

Hasan, Zubeir, "Sustainable development from an Islamic Perspective: meaning implications and policy concerns", JKAU: Islamic Economics, Malezija, 2006.

Moi, Mohammed Rizki, Mohd, Muhammad Hakimi i Possumah, Bayu Taufiq, "Concept of sustainable development from islamic perspective", The 3rd International Conference of Management and Muamalah 2016, Thailand, 2016.

Nuh, Muhammed, "Sustainable development in a muslim context", Exploring Synergies between Faith Values and Education for Sustainable Development, bez mjesta izdanja, 2012.

Patmawati, Ibrahim, Asmak, Abdu-Rahman i Siti, Arni Basir, "Sustainable economic development: concept principles and management from islamic perspective", European Journal of Social Sciences, Social Sciences Research Platform, Seychelles, 2010. 
Vedad Mustedanagić, MA

University of Bihac

Islamic Pedagogical Faculty

E-mail: vedadm1997@gmail.com

\section{SUSTAINABLE DEVELOPMENT FROM AN ISLAMIC PERSPECTIVE}

\section{ABSTRACT}

Achieving economic development suitable for all the population, which will combat poverty and at the same time not go to the detriment of nature and its wealth is one of the primary interests of all mankind. This imperative can be achieved by applying the principles of sustainable development. In this paper, we will present a successful model of conservation of natural resources, i.e. sustainable development from an Islamic perspective. For the application of sustainable development, it is important to present three components: economic (economy), social (society) and ecological (natural environment). These three components were presented separately as areas of Islamic science, and after their role in sustainable development was offered. These scientific disciplines that have been developed and assimilated into Islamic discourse flexibly and adaptably participate in the formation of sustainable development. Although they are separate areas, when it comes to sustainable development, they are connected into one cohesive unit and formulate an effective concept of sustainable development. We emphasize that sustainable development is implemented through individual and state responsibility. The individual participates in the preservation of the environment by adhering to established legal norms and refraining from its useless exploitation, i.e. by adhering to the concept of moderation. The role of the state or political activity is a more pronounced form of management because the government regulates the relationship and the use of natural resources for the population located in a given area, by prescribing a set of economic measures. We conclude that sustainable development has found its place in Muslim countries in various forms and sustainable architecture is one of the more serious factors of sustainable development as well.

Key words: sustainable development, Islamic environmental law, ecology, economics and sociology 
الأستاذ المعيد وداد موستيديناغيتش

جامعة بيهاتش

كلية التربية الإسلامية في بيهاتش vedadm1997@gmail.com

\section{التنمية المستدامة من المنظور الإسلامي}

\section{الخلاصة}

إن تحقيق التنمية الاقتصادية الملامٔة لجميع السكان والتي تكافح الفقر دون إلحاق الضرر

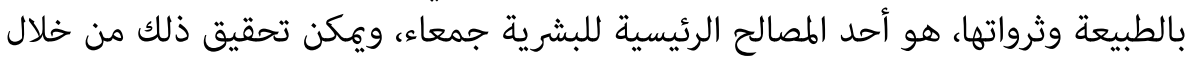
تطبيق التنمية المستدامة.

سنقدم في هذا البحث فوذجًا ناجمًا للحفاظ على الموارد الطبيعية، أي فوذجًا للتنمية

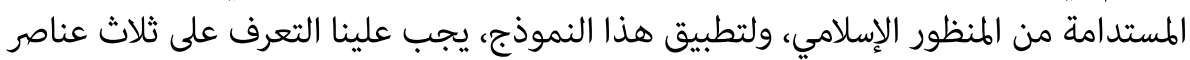

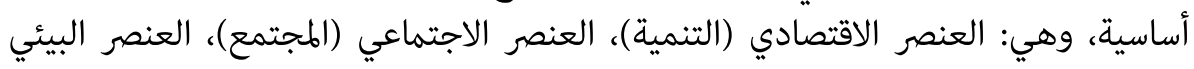

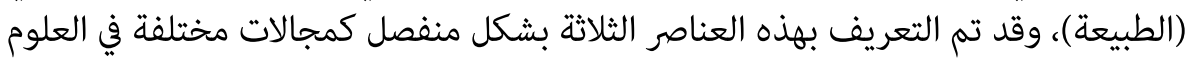

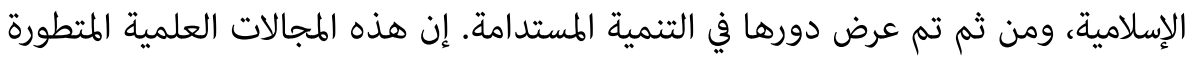

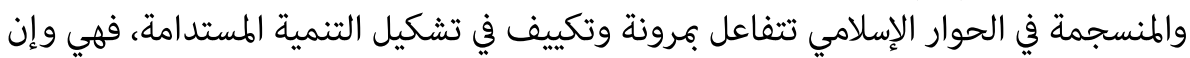

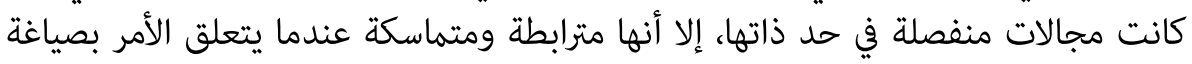
مفهوم فعال للتنمية المستدامة.

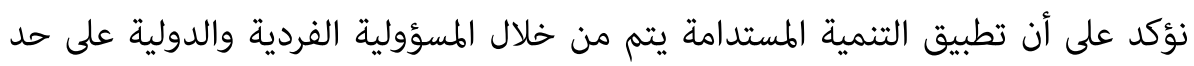

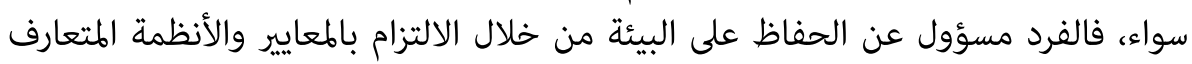

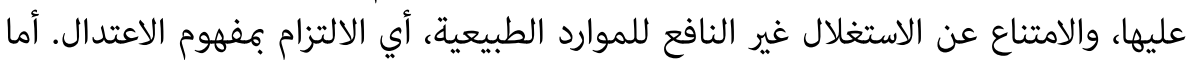

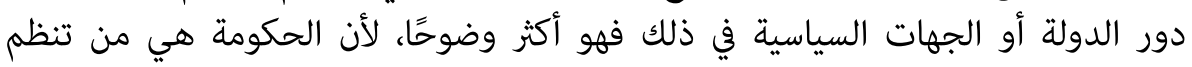

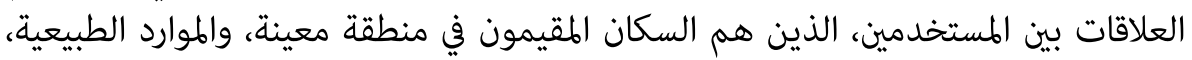
وهي التي تفرض مجموعة من التدابير الوقائية الاقتصادية.

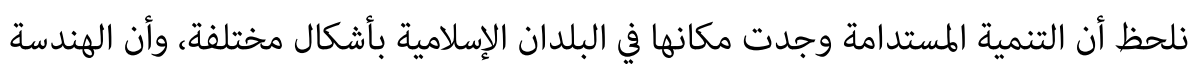
والعمارة المستدامة هي أحد العوامل الأكثر جدية في مجال التمال التنمية المستدامة. الكلمات المفتاحية: التنمية المستدامة، القانون البيئي الإسلامي، علم البيئة، علم الاقتصاد، علم الاجتماع. - ات 